\title{
The Influence of Transformational Leadership Style to Performance of Islamic Bank Bank with Work Motivation as a Mediating Variable
}

\author{
Muchran B. L. ${ }^{1} \&$ Muchriady Muchran ${ }^{2}$ \\ ${ }^{1}$ Economic Faculty, Muhammadiyah University of Makassar, Makassar, Indonesia \\ ${ }^{2}$ AMI AIPI, Makassar, Indonesia \\ Correspondence: Muchran B. L., Economic Faculty, Muhammadiyah University of Makassar, Makassar, \\ Indonesia. Tel: 81-24-23-0237. E-mail: muchranmuchriana@gmail.com
}

Received: March 24, 2017

Accepted: April 12, 2017

Online Published: May 9, 2017

doi:10.5539/res.v9n2p262

URL: http://doi.org/10.5539/res.v9n2p262

\begin{abstract}
This study aims to examine and analyse the influence of transformational leadership style to performance of Islamic bank Bank with work motivation as a mediating variable. Achievement of objectives of Islamic banking organizations and individuals as well as members of units simultaneously organization is the primary task of a leader. A leader can influence his followers are required to execute commands without using coercion, so that subordinates voluntarily behave and perform as demanded by the organization through referrals leaders. Transformational leadership not only recognizes the needs of subordinates, but also trying to trying to improve the needs of lower levels to higher levels to the level established. The sample of this research was Islamic Bank Employees on South Sulawesi. Repeated measure t-test was used to analyse the data in which the significance was determined by $\mathrm{p}<0.05$. The result showed that Transformational Leadership Style to Work Motivation significant effect. Transformational leadership style to performance of Islamic bank showed no significant effect. Work motivation to performance of Islamic bank showed no significant effect.
\end{abstract}

Keywords: transformational leadership style, work motivation, performance of Islamic bank

\section{Introduction}

\subsection{Background}

The basic building of efforts to apply the theory of Islamic economics really lies in the condition of the human factor as the culprit. Various views and efforts have been applied in improving employee performance in the Islamic Bank, but in essence it is believed that everything will not be separated and must be initiated by efforts to consistently form an Islamic leadership style as well. Ignoring the latter will in turn have an impact, which is a boomerang for the development and management of the Sharia Bank itself, because it means ignoring the importance of exemplary aspects as the basis and essence of all aspects of da'wah.

To adjust the goals (goals congruence) then required leaders who coordinate and direct the goals of members and organizational goals into harmony. The leadership context then becomes the subject first seen as an important part of the big picture of the conception of sharia banking organization.

Robbins (2001, p. 1) transformational leadership style is a leader who is able to inspire subordinates to prioritize the progress of the organization rather than personal interests, giving good attention to subordinates and is able to change the consciousness of his subordinates in seeing old problems in new ways. Transformational leadership influence his followers to change attitudes and basic values of his followers through empowerment. Motivation leader must have the appropriate way to motivate employees, and further pursued to achieve high performance, the Goal Theory states that a person's productivity or achievement depends on the motivation of the work they do. The higher the motivation for someone to do the job the higher the level of productivity and vice versa, the less motivation to do the work, the level of productivity is getting smaller. High motivation or activity characterized by a spirit of employees in carrying out their duties. Target banks using Islamic principles also must not only Islamic bank employee welfare itself but also the welfare of employees at businesses financed. It should be noted that conventionally, the employee benefits include salaries, training, education, health and so forth (Ibrahim et al., 2006, p. 114). This is showing an indication that business performance is closely related to the welfare of employees and 
employee performance. The purpose of this study was to examine and analyse the effect of transformational leadership style to the performance Islamic Bank with work motivation as a mediating variable.

Benefits of this research: 1) to understand and deepen the implementation of Islamic-based management (al-Qur'an and as-Sunnah) in the implementation of the organizational unit of Bank Syariah, 2) special science in the field of human resource development in accordance with the teachings of al-Qur'an and as-Sunnah on the management of Bank Syariah. It can also be used as an empirical study for the development of human resource management science in Syari'ah banking in Indonesia, 3) it is an additional work to organization of Islamic banks in South Sulawesi. It associated with the development of transactional and transformational leadership, Islamic work motivation; organizational Islamic commitment in the work unit to encourage the practice of human resource management that can be decision and at the same time can implement the teachings of Islam Al-Qur'an and as-Sunnah in motivating its leaders and employees towards the direction of more Islamic search results, 4) inter-organizational linkages and human resource management related to understanding transactional and transformational leadership behaviors, Islamic organizational commitment and Islamic work motivation, as well as Islamic performance in organizations that are guided by Islamic teachings, 5) for further study reference, issues related to morals and ethics, and morals in accordance with the Qur'an and as-Sunnah with a more kaffah scope to produce more perfect results and Can be used more perfectly.

\subsection{Based Theory}

Leadership. Leadership or leadership in Arabic is called the caliphate, Imarah, ziamah, and Imamat. Etymologically leadership means leading the style or quality of a leader or action in the lead itself. While the terminology there are several definitions of leadership. According to Davis et al. (2001, p. 161) that leadership is an ability to influence others in order to achieve certain goals that have been set, or in other words that the leadership is attempting to transform the potential pent into reality.

Types of Leadership. Type or someone different leadership styles depending on the character and the character of the leaders, destination and type of organization-led, demand-led social situations and so forth. As for the type or style of leadership can generally be grouped into five (Zainudin \& Mustaqim, 2005, p. 12), namely:

1) Autocratic leadership style by treating the organization he leads as private property, so that only his will alone that must take place and are less willing to pay attention to criticism of subordinates.

2) Militeristic, namely leadership style by using a military model (command) and usually commands a leader must be obeyed absolutely.

3) Paternalistic, that style of leadership always considered led never mature. Therefore leaders rarely give a chance to his subordinates to develop creativity, initiative and make decisions.

4) Charismatic, that style of leadership with more weight on the leader figure, usually hasmany followers, and they are willing to work leadership orders whatever.

5) Democratic, that style of leadership whose leaders are trying to synchronize between the interests and goals of the organization.

Path Goal Theory. The path-goal theory can be thought of as a process in which leaders select specific behaviours that are best suited to the employees needs and the working environment so that they may best guide the employees through their path in the obtainment of their daily work activities (Northouse, 2013).

Theory $\mathbf{X}$ and $\mathbf{Y}$. This theory gives emphasis on the aspects of employment and productivity at the expense of human values. But the workers strongly opposed to the ideas of scientific management by offering the era of human relationships as an alternative. Having started the golden era of humanity in the management approach, then Douglas McGregor (1970, pp. 314-315) straighten out his ideas in the theory of X with Y theory.

Leadership Transformational. Robbins (2001, p. 61) defines leadership transformational is a leader who is able to inspire subordinates to prioritize the progress of the organization of the personal interests, giving good attention to subordinates and is able to change the consciousness of his subordinates in seeing old problems in new ways. Transformational leadership influence his followers to change attitudes and basic values of his followers through empowerment. According Thobroni (2005, p. 40), the source of the influence of transformational leadership there are two power expertise and the power reference. "Transformational leaders improve his followers to grow on its own, improve self-esteem itself and serve as an independent person. Thobroni (2005, p. 40) concludes leadership transformational leadership is ethical".

Work Motivation. Rival (2009, p. 385), the motivation is essentially the process of trying to influence someone to do what we want. In other words, push from outside against someone to do something. Further Rival (2009, p. 
389), basically in every human being there is always a strong urge to want to progress, want to be better than others and getting stronger faith, it is increasingly realized that tomorrow is better than today.

Islamic Performance. In the Islamic perspective of work is the nature of human life, as well as ways to obtain happiness of life on earth and in the hereafter. Work also has a high position ranked second after faith, so that someone who works aim to obtain the blessing of Allah, because the work is "worship" and becomes an integral part of the characteristic attitude of life of people who converted to Islam. Thus Islam is very high regard for the effort and work that is "halal". Word of Allah contained in verses of the Quran, essentially encourage people to do business/work, among others, providing an impetus for work or trying to, then Allah and His Messenger and the believers will see your work, and you will be returned to (Allah) knows would be the unseen and the real, and preached into you what you used to do. Further on beam performance is also a faith that comes from belief systems, means that Islamic values with respect to employment, the automatic is an integral part of the Islamic faith. Similarly, the formation of a fundamental attitude toward work, certainly not loose relationship that blends performance with the Islamic faith. This was stated by Siagian (1992, p. 135). Creed is often expressed as faith and shari'ah with the phrase "pious charity".

\section{Hypothesis Development}

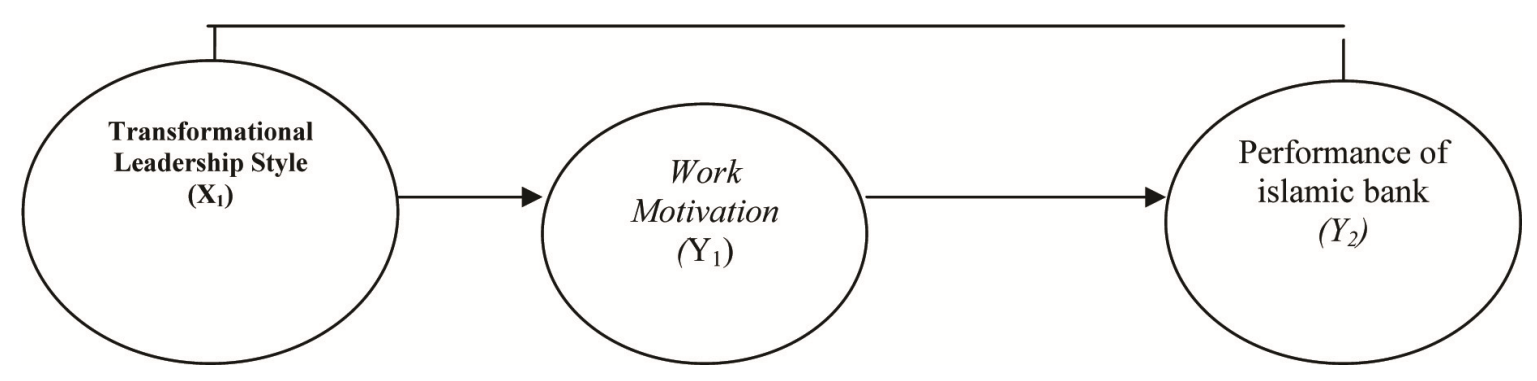

Figure 1. Research model

Here is the function of linear equations:

$\mathrm{Y}_{2}=\alpha+\beta_{1} \mathrm{Y}_{1}+\beta_{2} \mathrm{X}_{1}+\mathrm{e}$

Where:

$\mathrm{Y}_{1}=$ Work Motivation

$\mathrm{Y}_{2}=$ Islamic Employee Performance

$\mathrm{X}_{1}=$ Transformational Leadership Style

$\mathrm{a}=$ Constants

$\mathrm{e}=$ Error

Hypothesis is as follows:

Hypothesis 1: Transformational leadership style is positive and significant impact to work motivation.

Hypothesis 2: Transformational leadership positive and significant impact to performance of Islamic bank.

Hypothesis 3: Work motivation positive and significant impact to performance of Islamic bank.

\section{Method}

The population in this study were all employees of both leaders and subordinates in Islamic Banks in South Sulawesi. Based on existing data there are 10 commercial banks Sharia in South Sulawesi. The results of the analysis of this study are individuals (employees) and employees who need relevant data or in accordance with the issues raised in this study. Prerequisites used to select the sample that has been working in the company at least one year.

The sample in this study requires 186 people selected using random sampling method (random sampling method). The procedure of determining the sample of research in principle is stratified random sampling.

This study was designed to survey method. The survey was conducted by interviews and questionnaire. For testing and proving the hypothesis in this study, use all criteria and test for goodness of fit as well as a test for each 
individual coefficient (t-test) using a significance level $\alpha=0.05$. The whole symbol of coefficients to be obtained from the estimation model (of the AMOS software used) as well as the methods and analytical tools necessary estimates.

\section{Results}

\section{Hypothesis Testing}

Table 1. Estimate of influence coefficient whether direct and indirect or exogenous variables performance of the Islamic endogenous employees $\left(\mathrm{Y}_{2}\right)$

\begin{tabular}{ccccc}
\hline \multirow{2}{*}{ Hypothesis } & Influence the direction between variables & Coefficient Line & t-Statistic & Probability \\
\hline 1 & $\mathrm{X}_{1}=>\mathrm{Y}_{1}$ & $1,479 *$ & 3.772 & 0,000 \\
2 & $\mathrm{X}_{1}=>\mathrm{Y}_{2}$ & 1,556 & 1,488 & 0.137 \\
3 & $\mathrm{Y}_{1}=>\mathrm{Y}_{2}$ & -0.465 & $-1,216$ & 0,224 \\
\hline
\end{tabular}

*) Significant at $\alpha=5 \%$.

The direct influence of Transformational Leadership Style (X1) to work motivation (Y1) shows a significant influence with the $\mathrm{t}$ value of 3.772 and the coefficient value of 1.479 . This means that the better the transformational leadership style of a leader, the better is the motivation of the employee's Islamic work (based on the positive number on the coefficient value). Conversely, the worse the transformational leadership style of a leader, the employee's Islamic work motivation will decrease. This result is consistent with hypothesis that transformational leadership style is positive and significant impact to work motivation.

The direct influence of the transformational leadership style (X1) to performance of Islamic bank (Y2) shows an insignificant effect with the $t$ value of 1.488 and the coefficient value of 1.556. This means that both the transformational leadership style of a leader will have no effect on the performance of Islamic bank. This result is also inconsistent with the initial hypothesis that transformational leadership positive and significant impact to performance of Islamic bank.

The direct influence of work motivation (Y1) to performance of Islamic bank (Y2) shows an insignificant effect with $t$ value equal to -1.216 and coefficient value -0.465 . This means that whether or not an employee's work motivation will have an effect on the performance of Islamic bank. This result is not in accordance with the initial hypothesis that work motivation positive and significant impact to performance of Islamic bank.

\section{Discussion}

\subsection{The Influence of Transformational Leadership Style to Work Motivation at Islamic Bank}

Positive Influence and Significant Transformational Leadership Style towards Work Motivation at Sharia Bank in South Sulawesi, showing leadership style that comes from transformational leadership has influence and able to create good condition in its aim to increase employee work motivation. The leadership approach with transformational style makes the effort to change awareness, inspire and inspire subordinates or members of the organization to expend extra effort in achieving organizational goals, without feeling pressured or depressed, is considered capable of generating motivation of Islamic employee work.

This result is also consistent with the original hypothesis, which according to Gibson $(1995$, p. 8$)$ states that transformational leadership is a leadership to inspire and motivate followers to achieve results that are larger than originally planned and internal rewards. Furthermore, Robbins (2001, p. 61) defines transformational leadership as a leader capable of inspiring subordinates to prioritize organizational progress rather than personal interests, paying close attention to subordinates and able to alter the consciousness of their subordinates in viewing old problems in new ways. Transformational leadership influences his followers by altering the attitudes and basic values of his followers through empowerment.

Islam always encourages its people to encourage and motivate employees in performing their duties. Their performance and efforts must be acknowledged and they must be honoured if they work well. Employees who perform well and it may be rewarding or incentivizing to honour their achievements. Handoko (2001, p. 46), also states that $10 \%$ of time managers are used to develop ways to motivate employees. These methods are compatible with the transformational leadership style approach. 
Therefore, leaders should continue to develop capabilities in efforts to awaken and understand what motivates employees to keep working for better results. So also from the side of employees would still dig the potential of religion-based self, in order to increase the motivation that is formed always in the corridor Islamic.

Transformational Leadership Style to Work Motivation significant effect. Transformational leadership style of the performance of employees Islamic showed no significant effect. Islamic motivation to work on the performance of employees showed no significant effect. Based on the results, discussion and conclusions of this study, the following was conveyed some suggestions as inputs for the Islamic banking especially in South Sulawesi. For the employees, so that employees better understand the Islamic values of a different conventional and Islamic banking. So the sharia-based banking in practice is really based on Islamic ordinance is good and right. A good understanding of Islamic values is not expected to be created in the Islamic banking system but in everyday employees and ourselves. For the leaders, so that in addition to being an exemplary also have the ability, knowledge of the Islamic leadership that has been taught by the Messenger of Allah SWT. Also increases the associated expertise in Islamic approaches to increase the commitment, organization and performance of employees in Islamic banks in South Sulawesi.

\section{Conclusion}

According to Davis (1993, p. 32), explains that there are two variables that can affect performance. First: Individual variable is consisting of experience, education, gender, age, motivation, leadership, physical condition, personality and attitude. Second: is situational variable, that includes the physical and occupational factors which include work method, arrangement and condition, work equipment, work room arrangement, noise, irradiation and temperature; Further social factor from an organization which include; Policy, type of training and experience, wage/salary system and work environment.

This indicates if the two variables mentioned above have generally been met. Seeing the characteristics of employees working in syariah banks in South Sulawesi has an average level of education S1 is considered to have a good understanding of the process of performing in order to achieve the vision and mission of the organization. Likewise, when viewed from other aspects such as working environment conditions in banks that are generally well ordered and neat, so that work comfort can run well.

In addition, Islamic employees in sharia banks in South Sulawesi, generally understand the need of work in addition to the nature of human life is also merely seeking the blessings of Allah SWT. The Word of Allah (SWT) contained in the verses of the Qur'an, essentially encourages people to do business, among others, to give an encouragement to work, then God and his apostle and the believers will see your work, and you will be returned to (Allah) who knows of the unseen and the real, and then proclaim to you what you have done.

From the above explanation, in sharia commercial banks in South Sulawesi. Both the poor transformational leadership style does not affect Islamic performance in syariah banks in South Sulawesi. Thus, the closeness between leader and subordinate with transformational style does not significantly affect the performance of syariah bank in South Sulawesi. The approach that takes place between leaders and employees is more a form of socialization among fellow social beings. No factor will be generated on this leadership style on employee performance in sharia banks in South Sulawesi. The transformational leadership style based on employee approaches will serve as a supervisor and performance monitor of employees in an Islamic and friendly way.

Besides the performance is also a radiance belief that comes from the system of faith, meaning that Islamic values in connection with work, automatically is an integral part of Islamic aqidah. Similarly, the formation of basic living attitude towards the work can be sure not loose relationship performance that integrates with Islamic aqidah.

\section{The Influence Work Motivation to the Performance of Islamic Bank}

Fair, just and sufficient financial welfare for sharia banks in South Sulawesi may not affect work motivation, but can improve performance. The standardization of revenues in Syariah banks in South Sulawesi and a clear working system are considered to have satisfaction that drives employees to work well.

Described (Zadjulli, 1999) found several indicators of employee's Islamic performance variables include the following:

1) The results of a person's business or work accomplished in the presence of abilities and deeds in certain situations.

2) Working in the right way and good.

3) The work can be beneficial in life.

4) Seek the blessings of Allah SWT, because the call to become the chosen person. 
5) Proper, fair and sufficient financial welfare.

6) Gain opportunities for self-development.

7) Excellence of the quality of religious work (Islami) compared with non-Islamic.

8) Achievements achieved by someone as a manifestation of hard work and always want to go forward.

Improved performance in addition to the standardization of income that has been good, as well as Islam has emerged a good understanding also about working in tujaunnya seek God's blessings.

\section{References}

Davis, K. et al. (2001). Human Behaviour at Works: Organizational Behaviour (7th ed.).

Douglas, M. (1970). The Human Side of Interprise. In Management and Motivation (pp. 314-315). Baltimore: Penguins Books.

Ibrahim, A. A. (2006). Syari'ah Management: A Historical and Contemporary Study. In Interpreting: Dimyaudin. Jakarta: PT Raja Grafindo Persada.

Northouse, P. (2013). Leadership Theory and Practice. Thousan Oaks: Sage publications, Inc.

Rivai, V. (2009). Islam Human Capital from Theory to the Practice of Islamic Resource Management. Jakarta: Raja Grafindo Persada.

Robbins, S. (2001). Organizational Behavior (Vol. 2). Jakarta: Prenhallindo.

Siagian, S. P. (1992). Organizational Leadership \& Administrative Behavior. Jakarta: Rineka Cipta.

Thobroni. (2005). The Spiritual Leadership. Penerbit UMM Malang.

Zainudin, M. (2005). Study of Islamic Leadership: Normative and Historical Review. Yogyakarta: Publisher of Putra Mediatama Press.

Zadjuli, S. I. (1999). Principles of Islamic Economics, Surabaya: Faculty of Economics. Airlangga University.

\section{Copyrights}

Copyright for this article is retained by the author(s), with first publication rights granted to the journal.

This is an open-access article distributed under the terms and conditions of the Creative Commons Attribution license (http://creativecommons.org/licenses/by/4.0/). 